\title{
Foreign Direct Investment and Economic growth in Member Countries of Asia Pacific Trade Agreement
}

\author{
A. Muthusamy, Raghuveer Negi
}

\begin{abstract}
The economic growth depicts prosperity and self sustainability of nation. Foreign Direct Investment considered as handful tool for growth of host nation is a general perception all over the globe. Now due to global webbed market, countries worldwide are anxious to exploit Asia-Pacific's huge market and rich culture. The empirical evidence and fact-based case study poses FDI and economic growth on fringe due to variation in during the different span of time. This study attempted to analyze the relationship between FDI and economic growth into Bangladesh, China, India, Lao PDR, Mongolia, Korea Republic and Sri Lanka. It is assumed that blend of developed, emerging and developing economies taking as base for comparison will derive the more satisfactory result. Also, it consists of large market driven economies in the world due to strong market base. To attain the result of GDP growth, Inflation rate and Unemployment rate has taken as economic growth indicator. The Ordinary Least Squares, Augmented Dicky-Fuller and Granger Causality test is used to estimate the effect of FDI on economic growth. The result shows that in spite of consistent pattern in FDI inflow not all the countries have experienced the significant effect of FDI on economic growth of nation. The implications in nation's policies are discussed in the study.
\end{abstract}

Keywords : FDI, Economic Growth, GDP, Inflation, Unemployment, OLS, ADF, Granger Causality.

\section{INTRODUCTION}

The economic growth depicts prosperity and self sustainability of nation. Foreign Direct Investment plays a major role in economic development by inviting not only foreign entity but also brings foreign exchange in country. It removes the constraint between brain-drain, technology, innovation, infrastructural development, incubation centers. It instigates a nation to new market dynamics and moreover it flourishes new work culture among the nations. The foreign direct investment is an investment in the form of a controlling ownership in business in one country by an entity based in another country. The controlled and balanced growth is possible only through the coherent government policies, preserving the resources of nation, potent authority and harking back at social corporate responsibility. Foreign Direct investment is centre

\footnotetext{
Revised Manuscript Received on September 25, 2019

Dr. A. Muthusamy, Professor, Department of International Business, Alagappa University, Karaikudi

Raghuveer Negi, Full-Time Research Scholar, Department of International Business,Alagappa University, Karaikudi
}

for economic growth for following reasons; namely (a) It bring capital from foreign countries (b) supports foreign exchange inflows (c) removes constraints on balance of payments (d) it stimulate technology, innovation and advanced management skills (e) promotes exports of host country and fuel competitiveness in market.

The study focuses on impacts of foreign direct investment (FDI) on economic growth of member countries of Asia Pacific Trade Agreement (APTA). The Asia-Pacific region is always been enticing, alluring and captivating since ancient times. It tempted Europeans and British's in ancient times. Now due to global webbed market, countries worldwide are anxious to exploit Asia-Pacific's huge market and rich culture. India and China leading this region in world to propel foreign direct investment from developed countries. The World Bank considered Lao as one of the East Asia and Pacific's fastest growing economy with $7.8 \%$ annual growth in GDP for the past decade. Bangladesh is still struggling to attract fresh FDI due to socio-economic inequalities, corruption, terrorism and illiteracy. In Mongolia sectors such as geology, mineral exploration, mining, oil industry, trade and catering service sectors attracting the foreign investments from more than 112 countries (Department of Foreign Trade and Economic Cooperation, Ministry of Foreign Affairs, Mongolia). The overall record of foreign investment broke in South Korea in 2018 which is solemnly pledged by European, US and Chinese companies. According to the Ministry of Trade, Industry and energy in South Korea the FDI inflow is increased by $17 \%$ in 2018 proportionate to 2017. The civil war in Sri Lanka vandalized the structure of foreign investment till 2009. Now it is a different place the FDI in Sri Lanka grew to over USD 1710 billion during 2017-2018.

The FDI is considered as an important factor in economic growth due to benefit attained through investment from foreign entity but its influence and inherent limitation is still an argued topic. The 
investments from abroad and its impact on economic growth intrigued scholars, academicians and economist since 1960s. The sagacity of majority believes FDI derives economy towards growth in host country but empirical evidence is mixed due to heterogeneity of micro and macro variables which indicates economic growth of nation. Even if the foreign direct investment inflow varies investment concept stipulate a theory that if capital inflow in host country it will stimulate the economic growth. Although, contradiction of economic integration is inappropriate by considering foreign investment always cause economic growth. The existing belief on foreign investment for economic growth is undeniable but impact measure can varies on time scale, industrial diversity and availability of resources in host nation. In today's globalized world glance at foreign investment always been a moot within government, practitioners, economists, policymakers, academicians and scholars. The empirical study will give clear outline and help researcher to understand the relationship between foreign direct investment and economic growth.

\section{LITERATURE ADMITS THE RELATIONSHIP BETWEEN FDI AND ECONOMIC GROWTH}

Alfaro, Laura (2003) found evidence that there is ambivalent effect of FDI on economic growth of host nation. The primary sector noted the negative growth with foreign investment inflow, however the positive growth is observed in manufacturing sector. The effect of foreign investment inflow on service sector distinguished double-edged. This study proposed that not all forms of foreign investment benefits host countries and suggests to attract various forms of FDI and even if its negative in certain type, in particular investment in natural resources. Borensztein, Eduardo \& de Gregorio, Jose \& Lee, Jong-Wha (1995) found out that FDI contributes to economic growth only if sufficient adaptive and advanced technologies are available in host economy. The study suggests that FDI is significant for the transfer of technology which contributes more as compared to domestic investment. Also, the higher productivity also depends upon the minimum threshold stock of human capital in host nation. The study by Nair-Reichert, Usha \& Weinhold, Diana (2001) stated the fact that they do find a casual relationship from FDI to growth and evident the higher efficacy in more open economies, although the relationship also found heterogeneous across developing countries. This study proposed the in-depth research on specific micro-economic mechanism though which FDI and human capital which is foremost factor in order to identify those factors which determine the strong relationship between FDI and economic growth.
Chandana Chakraborty \& Peter Nunnenkamp (2008) studied the growth effect of FDI in various sectors. In manufacturing sector noted the mutual reinforcement between FDI stocks and output but casual relationship wasn't found in primary sector. In service sector they found transitory effect of FDI output. Sasi lamsiraroj, Mehmet \& Ali Ulubaşoğlu (2015) noted FDI cause economic growth because voluntary exchanges reflected in foreign direct investment. Moreover they found FDI and Economic growth relationship implied globally, there is no evidence found which reveal that FDI benefitting the developing nations more than developed countries. V.N. Balasubramanyam, M. Salisu \& David Sapsford (1996) tested the hypothesis framed by Jagdish Bhagwati, which says FDI enhances growth more in those nations who adopt export promoting (EP) policy as compared to import substituting (IS) countries. And empirical evidence from study appears to provide degree of support to proposed hypothesis by Jagdish Bhagwati. Baldwin, Richard \& Braconier, Henrik \& Forslid, Rikard (1999) this paper focused on pro-growth role of MNCs in host nation. In theoretical model MNCs plays a significant role in determining growth rate in long run through technological spillover. Also, empirical evidence broadly supports this model. Tabassum, Nafeesa \& Ahmed Samiul (2014) in their study evaluated the association between FDI and economic growth using multiple regression method taking real GDP, FDI and domestic investment and accessibility of the trade policies. They observed domestic investment deploy positive influence on growth whereas accessibility of trade policy regime is less significant under foreign direct investment. Wai Mun, Har \& Kai Lin, Teo \& Kar Man, Yee (2009) used Ordinary Least Square (OLS) regression and conducted empirical analysis on FDI and economic growth in Malaysia. The paper has sufficient evidence that economic growth and FDI inflow have significant relationship in Malaysia. Mani, Madhavan \& Nithyashree, MU (2016) in their study made an attempt to study the relationship between FDI and Economic Growth considering "Make in India" initiative of Government of India. They concluded that benefits are enormous compared to drawbacks due to FDI inflow. Gupta \& Garg (2015) study reveals that FDI to makes its contribution in economic growth in host nation requires three years of time. Also, to gain orderly growth continuity in FDI inflow is essential. Sengupta, P. \& Puri, R. (2018) studied pattern of FDI into Indian Subcontinent and its neighboring countries and explored the causality between FDI and GDP. In this study they found that differences in FDI Inflow very much depends upon the policies of respective countries and association between FDI and GDP is noted in all cases. They concluded 
the paper considering FDI as significant instrumental ground for economic growth in countries. Zhang, Kevin (2001) stated that FDI tend to promote economic growth if host nation endorse liberalized trade regime, quality education, and availability of efficient human resources and promote exports. Also, it maintains the macroeconomic stability of host nation. Xiaohui Liu, Peter Burridge \& P.J.N. Sinclair (2002) investigated the causal links between FDI inflow, trade and economic growth in China at the aggregate level. They found bi-directional causality between economic growth, FDI and export. Also, economic growth, export and FDI support more widely under open-door policy. Mungunzul, Erdenebat \& Chang, Taikoo (2018) in their study estimated the FDI determinants in Mongolia to detect the links between FDI and economic development. The result shows the positive and significant effect on the FDI inflow on GDP. It also states that investment in Mongolia either routed from far distant countries or too close to Mongolia which pays less attention towards Mongolian FDI inflow. Anittaphommahaxay and Bounlert Vanhnalat (2015) they estimated the effect of FDI on economic growth in Lao PDR at aggregate and disaggregate levels. The result indicated FDI inflows perspective in manufacturing sector is quite significant to support economic growth. They impelled for trade openness and labor factor for sustainable economic development. Ridzuan, Abdul Rahim \& Ismail, Nor Asmat \& Fatah, Abdul \& Idham, Mohamad \& Pardi, Faridah (2017) they conducted study to measure the impact of FDI and trade openness on sustainable development consists growth, income distribution and environment in South Korea and France. The ARDL model shows that FDI inflows led country towards growth with minimal pollution level but widened the income inequality in South Korea. On other hand Trade openness contributed to raise the income distribution but impact is nothing when it comes to growth and environment sustainability. In France foreign investments reduced the income inequality but there is no impact on growth and environment quality and Trade openness have positive impact on growth. M M Mustafa, A \& Santhirasegaram, S. (2014) they used Multiple regression models to estimate the impact of FDI on economic growth in Sri Lanka. The empirical evidence shows that actual impact of FDI can be seen after time lag of two years.

\section{DATA}

The researcher took member countries of Asia Pacific Trade Agreement which consist Bangladesh, China, India, Lao PDR, Mongolia, Korea Republic and Sri Lanka. The study period is from 1991-1992 to 2017-2018. The data for study collected from different sources such as World Bank Indicator, Annual Reports, Journals, Magazines and News dailies.

\section{RESEARCH OBJECTIVE}

In this study, the researcher evaluates the impact of foreign direct investment on economic growth of host nation. The study includes member countries of Asia Pacific Trade Agreement (APTA) as case study due to its gigantic economic scope. The study includes Bangladesh, China, India, Lao PDR, Mongolia, Korea Republic and Sri Lanka. There is obvious variation in foreign investment betwixt the countries which results in growth difference. Also, the disparities in trade policies and restriction can observe from nation to nation. Although, enormous study is already available on impact of FDI on economic growth but authors overlooked the study needs in regional economic integrations and blend of developing and developed nation together to speculate the well grounded evidence to disclose the link between FDI and economic growth. In this study, economic growth indicator consist GDP growth, FDI share in GDP, inflation rate and availability of labor.

\section{GDP Growth and FDI inflow swings among Asia Pacific Trade Agreement countries}




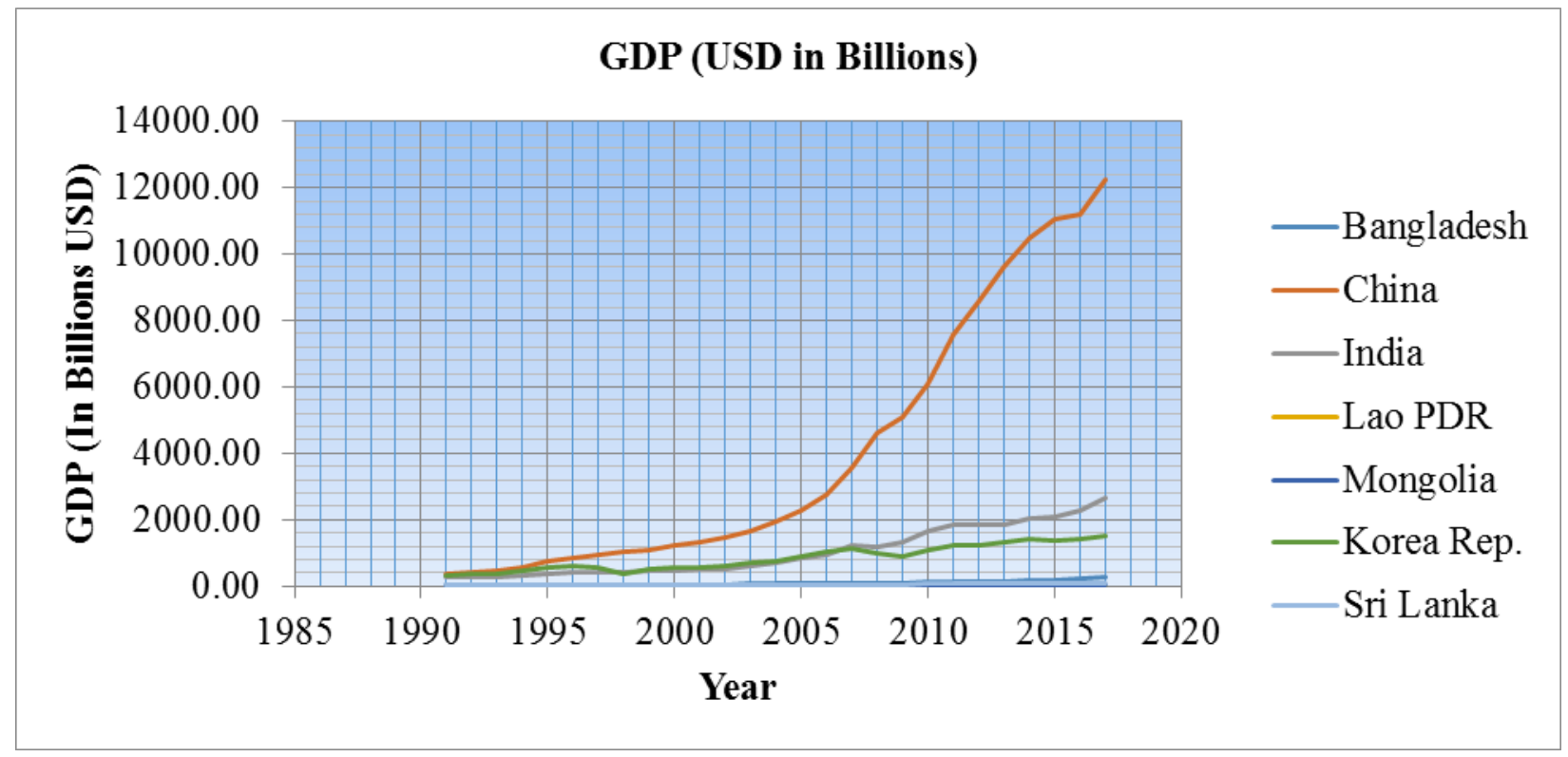

Figure 1. GDP overview of countries under Asia Pacific Trade Agreement.

From Figure 1, it is clearly seen that China leading the countries under APTA in terms of GDP. The author observed the upward trend in GDP growth rate of China and India in past 27 years. The global economic slow-down in 2008-2009 has minor impact on GDP growth of China and India. The Korea Republic was chasing China GDP in early 1990s but due to economic strain it failed to compete with China. Now Korea Republic GDP is stagnant at one point and highly volatile at another. However the Bangladesh GDP growth is in positive axis, still it's far behind from China, India and
Korea Republic. On other hand Lao PDR and Mongolia GDP growth is almost flat which depicts the stagnant growth. Sri Lanka shows the positive trend in GDP growth but at slower rate.

There is a wide difference in time the above mentioned countries took to adopt open trade and liberal economic policies which can be a key to understand their GDP growth pattern. Also, the investment criteria vary from country to country which can cause the growth pattern of respective countries.

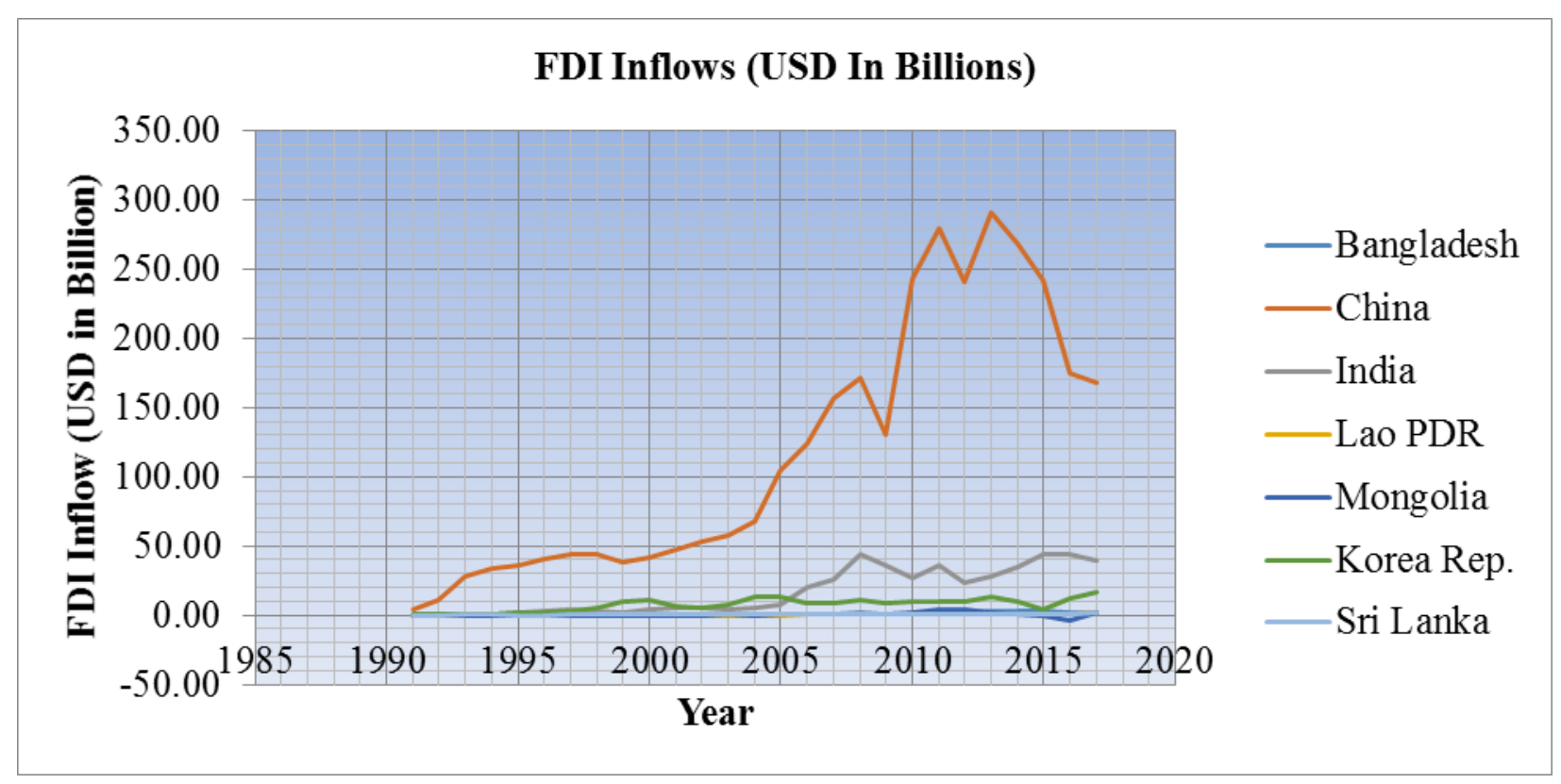

Figure 2. FDI inflow overview among the countries under Asia Pacific Trade Agreement.

In Figure 2, FDI inflow growth in China and India has been buoyant and in upsurge since the globalization and liberalization of country. There is a shortfall noticed during global crisis 2008 and 2009 but ever since its shows the positive growth. The Korea Republic, merely seen any promising growth in FDI since 1990s due to uniform shift in foreign investments. The foreign investment in Mongolia has observed the continuous fall along with eruptive rise. The FDI inflow in Bangladesh and Sri Lanka is growing slowly and steadily. Also, there is a shortfall due to economic recession but they

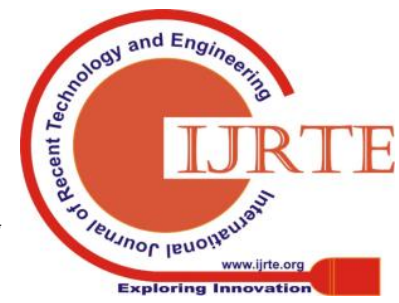


recovered by time with minor impact on investments.

An individual contours on FDI growth and policies which determine and dictated the growth of foreign investors in country.

\section{Bangladesh}

Bangladesh has attracted lesser foreign investment as compared to other respective countries since 1991-1992 to 2017-2018. Till 1993 FDI inflow remained insignificant but there is a growth in FDI slowly but steadily because it offers the most liberal investment policies in South Asia (Ferduasy, Shameema \& Rehman, Md., 2008). A study concluded that there is no significant FDI in country despite of all efforts of Government of Bangladesh. The author pointed out that political risk as major problem and had impact on FDI by slow pace in Privatization, business cost, related tax and other financial risk (Wali I. Mondal, 2003).

As we can see (figure 2) FDI inflow reached USD 2.15 billion in 2017-2018 as compared to USD 1.39 million in 1991-1992. Still, the major drawback of Bangladesh to attract foreign investment is government control which isn't substantial for foreign investors. The excessive bureaucratic interference, irregularity in paper work, sudden changes in tariffs and carelessness of local investors are other reasons for lesser investment so far now. The GDP of Bangladesh calculated USD 249.72 billion in 2017-2018 (see figure 1).

\section{China}

The FDI inflow in China observed the massive growth along with economic growth. It rose from USD 4.37 million in 1991-1992 to USD 168.22 billion in 2017-2018 which is sky-high growth as compared to other respective countries (see figure 2). It's dominating the Asia and pacific region economy with its major success story in foreign investments. Also, it's leading in terms of growth in Asia-Pacific region with calculated GDP of USD 12237.70 billion (see figure 1). A study by Cai, Francis \& Cheng, Huifang \& Xu, LianZan \& Leung, C.K.. (2011) concluded their paper by stating FDI as a engine in initial stage for economic development and turned to be main force in post-industrialization. During 1992-1993 and 1993-1994 China evidenced the massive increase of 150 per cent growth each year (Lai, P. 2002).

The success story of China in foreign investment based upon the foundation laid by strong government along with availability of capital, effective and efficient regulation authority, competitiveness and stability in market and their openness for global trade.

\section{India}

Indian Council of Cultural Research stated that In spite of severe socio-economic challenges, India inclined as a fastest emerging economy in global market. It gave access to modern technology in country by allowing 100 per cent FDI in defense through government route which was 49 per cent earlier, 74 per cent FDI allowed in pharmaceutical ventures and most of the sectors are now automatic approval route making. Thus, it makes India the most open economy for foreign investment as well as global market (Thomas, Asha. 2016). A study conducted by Jha, Raghbendra (2003) stated that India's principal problem remains the same to boost its rate of savings and Investment and compete with Chinese and East Asian economies. FDI became important because it's contributing towards technology progress, productivity spillover and slot in global export market. The India has the highest GDP after China in region with USD 2650.73 billion in 2017-2018(see figure 1).

India is chasing China and listed second for attracting the foreign investment which merely accumulated USD 73.53 million during 1990-1991. In 2017-2018, FDI inflow in India reached to 39.97 billion (refer figure 2), no doubt there is a wide difference in China and India's foreign investment but India is ready to take China with its more open economic policies.

\section{Lao PDR}

In 1991 Lao PDR stimulated the FDI worth USD 6.9 million in 1991-1992 reached investment up to USD 1.6 billion in 2017-2018. The trend and transition in foreign capital inflow of Laos increased since the FDI law 1988 enacted widely in nation. The study concluded stating that FDI contributed in socio-economic development, foreign exchange earnings, employment creation and technological advancement (J. Gunawardana, Pemasiri \& Sommala, Sisombat 2009). After Mongolia, Lao PDR have the lowest GDP with USD 16.85 billion (See figure 1).

The FDI in Laos mainly invested in resource sector (hydropower and mining), it can cause the Dutch disease. To develop Special Economic Zones to diversify FDI is practical and commendable step and it will improve the Lao economy (Kyophilavong, Phouphet \& Nozaki, Kenji. 2015).

\section{Mongolia}

The Mongolia experienced its own revolution in the year 1990-1991. The next decade brought significant changes in politics, social and economy. The mineral resource sector of Mongolia propelled the economy forward with potential demand from China (Christopher MacDougall, 2015). The Mongolia absorbed the foreign investment adroitly in past 27 years and contended with Mongolia closely in region. The Government of Mongolia failed to execute the investment reforms they committed to investors and institutional efforts to practice law are almost null which can seriously damage the country's economy. Also, Mongolia has lowest GDP in the Asia-Pacific calculated USD 11.43 billion (refer figure 1).

\section{Korea Republic}

The FDI inflow of Korea Republic or South Korea hit a record high of USD 17.5 billion in 2017-2018 (see figure 2). The performance of Korean FDI investment is not as impressive as China. Both nations accumulated relatable foreign investment during 1991-92 but after 27 years the foreign investment inflow gap seems wider than early illustration. The GDP of Korea Republic chasing India and China in pacific region with USD 1530.75 billion (see figure 1). The study shows main determinants of FDI in Korea is openness, infrastructure and human capital otherwise dominancy is determined through industrial sectors and regions (Kang, Gil Seong \& Won, Yongkul. 2017). Jimmyn Parc, Jin Sup Jung, (2018) found out the actual effect of unconventional FDI is more positive with better management and larger than perceived.

\section{Sri Lanka}

The Sri Lankan's FDI inflow is way more volatile than any other respective countries. In 
1991-1992 it attracted USD 48.34 million, till 2005-2006 authors observed ups and downs in investment but increased simultaneously till global economic slow-down. After, it took them three years to recover and reach USD 1.37 billion foreign investment (see figure 2). The GDP of Sri Lanka grew from USD 9 billion up to USD 87.36 billion in past 27 years (see figure 1). After the end of 30 years long civil war FDI can play a major role in economic development. The trade openness, market size and infrastructure level has the positive impact and political stability and wage has the negative impact (Ravinthirakumaran, Kalaichelvi \& Selvanathan, Eliyathamby \& Selvanathan, Saroja \& Singh, T. 2015).

\section{RESEARCH METHODOLOGY AND EMPIRICAL EVIDENCE}

In this study author used regression analysis to investigate the relationship between one or more exploratory variable and one dependant variable. In this study, regression model is dependent variable $y_{t}$ is addressed as a linear combination of the exploratory variable $x_{1}, x_{2} \ldots, x_{t}$ :

$y_{i}=\beta_{1} x_{1 i}+\ldots+\beta_{p} x_{p i}+\varepsilon_{i}$

Where $x_{i j}$ is the $i$ th observation on the $j$ th dependant variable $b_{1}, \ldots, b_{p}$ are the regression coefficient and $\varepsilon$ is the error term.
The data in study used from annual data of GDP growth rate, Inflation rate, Unemployment rate and FDI as a percentage of GDP from 1991-1992 to 2017-2018. The data have been taken as economic growth indicators from the World Bank.

We build the simple linear regression models corresponding to each country. We cast the following regression model.

$$
\begin{gathered}
X=\beta_{1}+\beta_{2} Y+\varepsilon_{i} \\
X_{1}=\beta_{1}+\beta_{2} Y_{1}+\varepsilon_{i} \\
X_{2}=\beta_{1}+\beta_{2} Y_{2}+\varepsilon_{i}
\end{gathered}
$$

After fitting the model containing GDP growth, Inflation Rate and Unemployment Rate are dependent on FDI share in GDP. In analyses each equation contains the one dependent (for example GDP growth) and one independent (FDI share in GDP). Likewise regression calculated between Inflation rate and FDI, and Unemployment Rate and FDI growth. We get the following result (refer Table 1).

Table 1. Results from the Individually Fitted OLS Model for the Countries

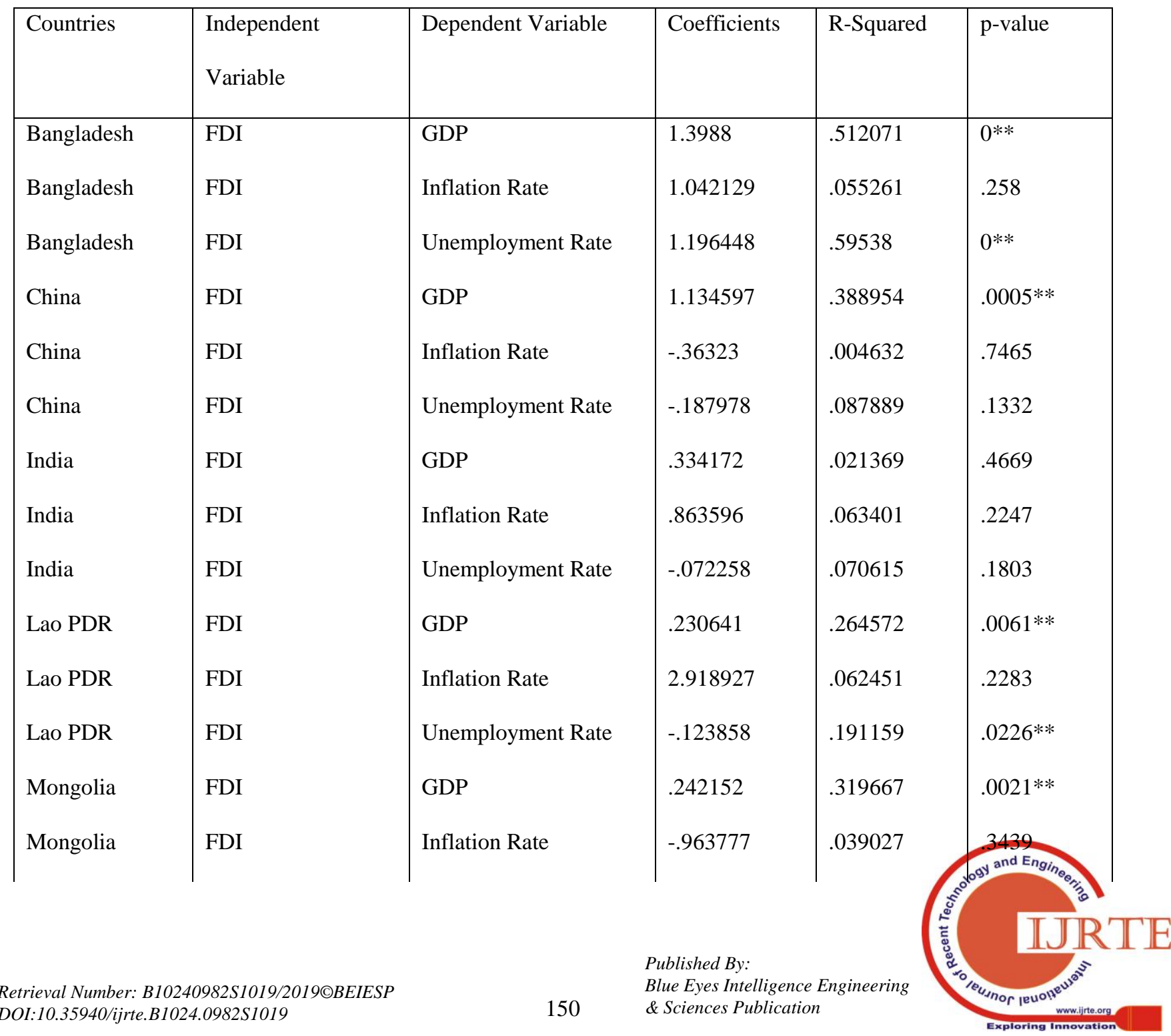




\begin{tabular}{|l|l|l|l|l|l|} 
Mongolia & FDI & Unemployment Rate & -.028228 & .178848 & $.028^{* *}$ \\
Korea Republic & FDI & GDP & -1.089919 & .026916 & .4135 \\
Korea Republic & FDI & Inflation Rate & -.981203 & .095785 & .1322 \\
Korea Republic & FDI & Unemployment Rate & 1.513847 & .530695 & $0 *$ \\
Sri Lanka & FDI & GDP & 1.220308 & .080214 & .1523 \\
Sri Lanka & FDI & Inflation Rate & -1.393201 & .022838 & .4709 \\
Sri Lanka & FDI & Unemployment Rate & 1.220308 & .080214 & .1523 \\
\hline
\end{tabular}

Note: *Significant level at 5 percent

Result: Computed by Author based on World Bank Data

It is evident from empirical analysis that in Bangladesh, Lao PDR and Mongolia depicts the maximum effect of FDI on economic growth among other respective countries. To an extent there is an effect of FDI on economic growth of China and Korea Republic. India and Sri Lanka shows insignificant effect of FDI on economic growth among other countries.

Before performing causality analysis, author analyzed the stationarity of the data with the help of following equation.
$\Delta y_{i t}=\alpha y_{i t-1}+\sum_{j=1}^{p i} \beta_{I J} \Delta y_{i t-1}+x_{i t} \delta+\varepsilon_{i t}$ (4)

The results are provided in Table 2. The author used the augmented Dicky-Fuller (ADF) unit root test in Eviews; the test statistics and $p$-values are displayed. At a level of significance 5 per cent FDI share in GDP, GDP growth, Inflation rate, Unemployment rate of all countries data meet stationarity after first-difference except Korea Republic and Sri Lanka. The stationarity of data meet at the level itself for Korea Republic and Sri Lanka.

Table 2. Results from the Augmented Dickey-Fuller Test

\begin{tabular}{llllc}
\hline Countries & ADF test stat & $\mathrm{p}$-value & First difference & $\mathrm{p}$-values \\
\hline Bangladesh & -1.662674 & .43 & -2.958091 & $\mathrm{p}<.05$ \\
China & -2.321864 & .173 & -4.145576 & $\mathrm{p}<.05$ \\
India & -1.964226 & .2997 & -5.604561 & $\mathrm{p}<.05$ \\
Lao PDR & -1.722582 & .4087 & -4.998737 & $\mathrm{p}<.05$ \\
Mongolia & 2.343963 & .9999 & -6.553425 & $\mathrm{p}<.05$ \\
Korea Republic & -3.015322 & $\mathrm{p}<.05$ & & \\
Sri Lanka & -4.908892 & $\mathrm{p}<.05$ & & \\
\hline
\end{tabular}

Note: *Significant level at 5 percent

Result: Computed by Author based on World Bank Data

The estimate the causality between Variables FDI share in GDP and GDP growth, FDI and Inflation rate, FDI and Unemployment rate Granger Causality test is used. The 
$\Delta x_{t}=\gamma_{0}+\sum_{i=1}^{M} \gamma_{1} \Delta y_{t-i}+\sum_{j=1}^{N} \gamma_{2} \Delta x_{t-j}+\gamma_{3} \delta_{t-1}+\omega_{t}$ (7)

In this equation $\mathrm{I}, \mathrm{L}, \mathrm{M}$ and $\mathrm{N}$ are optimal lag length and $\mathrm{e} 1$ and $\mathrm{w} 1$ are the error terms which are free of any serial correlation. The results exhibited in Table 3.

The results in Table 3 show the granger causality between FDI and economic growth (economic growths indicators are GDP, Inflation rate and Unemployment rate) for seven countries. From Table 3, we can reject the null hypothesis that FDI does not Granger Cause inflation rate in China, Unemployment rate does not Granger-cause in India, FDI does not Granger-cause GDP growth rate in Lao PDR, GDP growth rate does not Granger-cause FDI in Mongolia and Unemployment rate does not Granger-cause FDI in

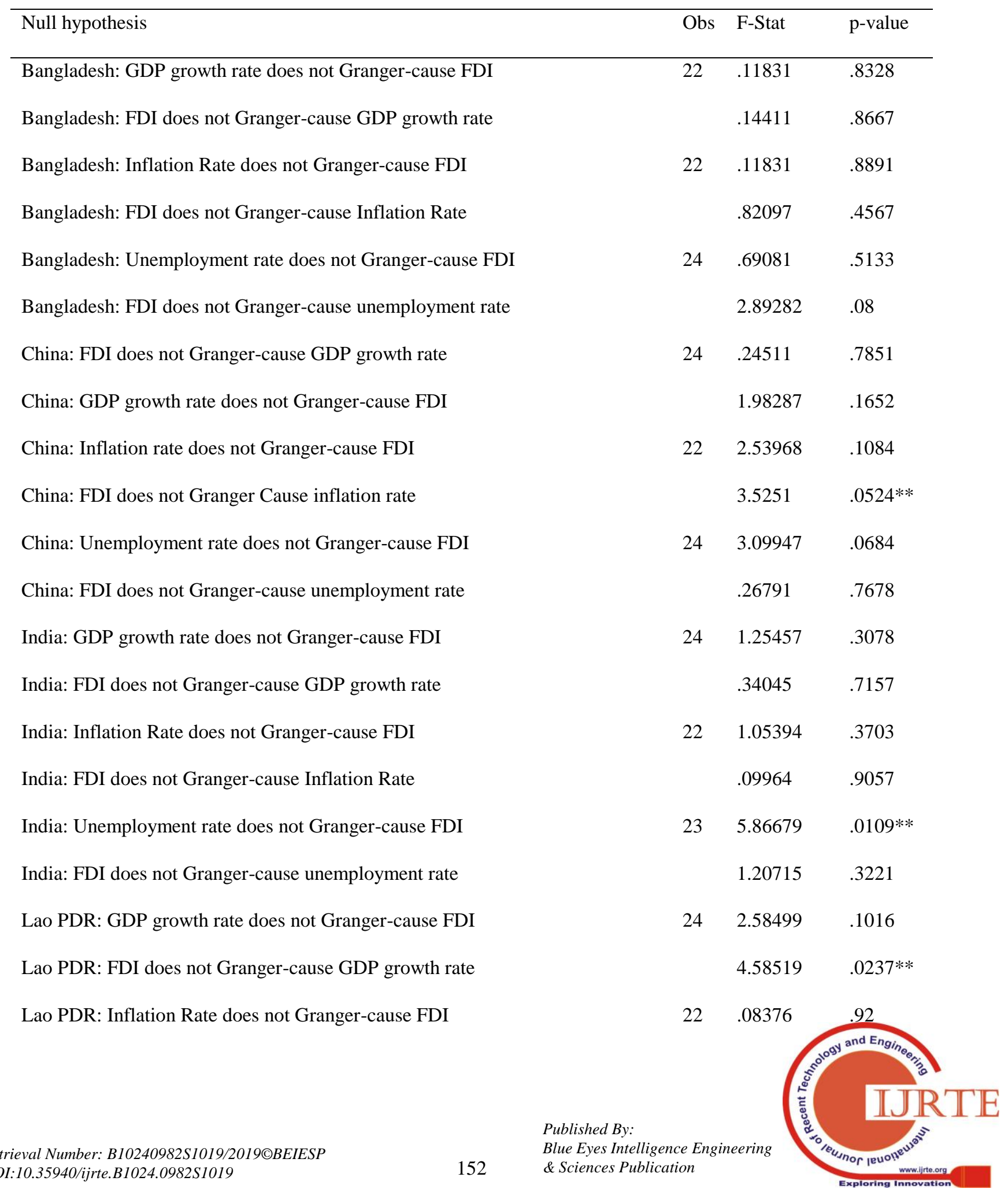

Mongolia because p-value is smaller than level of significance we determined previously. We cannot reject the null hypotheses that FDI does not Granger-cause GDP in all other respective countries excluding Lao PDR because $p$-value is too high. Also, we have to accept the null hypotheses that FDI does not Granger-cause Inflation rate in all respective countries studied in paper excluding China because $p$-value is higher than significant level. Also, there FDI does not Granger-cause unemployment rate in all 7 countries. Thus, a unidirectional long run relationship can be seen between FDI and Inflation rate in China, and FDI and GDP growth in Laos. Otherwise there is no evidence of relationship between FDI and economic growth in studied countries.

Table 3. Results from Granger Causality Test 
Lao PDR: FDI does not Granger-cause Inflation Rate

Lao PDR: Unemployment rate does not Granger-cause FDI

Lao PDR: FDI does not Granger-cause unemployment rate

Mongolia: GDP growth rate does not Granger-cause FDI

Mongolia: FDI does not Granger-cause GDP growth rate

Mongolia: Inflation Rate does not Granger-cause FDI

Mongolia: FDI does not Granger-cause Inflation Rate

Mongolia: Unemployment rate does not Granger-cause FDI

Mongolia: FDI does not Granger-cause unemployment rate

Korea Republic: GDP growth rate does not Granger-cause FDI

Korea Republic: FDI does not Granger-cause GDP growth rate

Korea Republic: Inflation Rate does not Granger-cause FDI

Korea Republic: FDI does not Granger-cause Inflation Rate

Korea Republic: FDI does not Granger-cause unemployment rate

Korea Republic: Unemployment rate does not Granger-cause FDI

Sri Lanka: GDP growth rate does not Granger-cause FDI

Sri Lanka: FDI does not Granger-cause GDP growth rate

Sri Lanka: Inflation Rate does not Granger-cause FDI

Sri Lanka: FDI does not Granger-cause Inflation Rate

Sri Lanka: Unemployment rate does not Granger-cause FDI

Sri Lanka: FDI does not Granger-cause unemployment rate
Note: *Significant level at 5 percent

Result: Computed by Author based on World Bank Data

\section{DISCUSSION}

As we can see, empirical analyses disclose the consistent effect of FDI on economic growth of developing countries such as Bangladesh, Lao PDR and Mongolia. Also, it shows insignificant effect of FDI on economic growth of India and Sri Lanka. There is an effect of FDI on economic growth (indicator used by author) of China and Korea Republic to some extent only. The more comprehensive result revealed through Granger Causality Test which shows there FDI causing economic growth at marginal contrary to general perception regarding foreign investment that FDI play a major role in economic growth of host nation. The FDI inflow in China and India is impressive but effect of FDI on economic growth in India is insignificant while in China it does effected the Inflation rate. It is clear that Bangladesh has lesser FDI inflow as compared to China, India and Korea Republic. The $p$-value estimated for FDI in regression model shows that it has significant effect on GDP growth and unemployment rate on one hand and on another hand result shows insignificant effect on inflation rate in linear regression model. The Granger causality test displays fragile results on effect of FDI on economic growth which back the argument that FDI in Bangladesh does not have overly significant effect on economic growth. Rahaman and Chakraborty (2015) in their study stated FDI as an insignificant factor for economic growth.

In China FDI inflow is inflated at apex and leading in Asia-Pacific region during study period. There regression model shows FDI has significant impact on GDP growth but does not confirm the strong 
connection. The Granger Causality Test exhibits it has strong impact on inflation rate. Both results show effect of FDI is almost nil on unemployment rate of China. However, foreign investment considered as a major backbone for Chinese economy.

In India author do not see any significant effect of FDI on GDP growth as well as on inflation rate. Despite of its major holding in FDI inflow after China still empirical evidence clearly shows that there is lesser effect of FDI on economic growth. The studies show that unemployment rate has direct effect on FDI inflow (Noorbaksh et al, 2001) which we also observed in our study. The Granger Causality supports the statement because unemployment rate Granger-cause the FDI inflow. A study by Sengupta and Puri (2018) found the effect is not significant of GDP on FDI which observed in our study as well.

After running regression model Lao PDR and Mongolian economy recorded the significant effect of FDI on GDP and unemployment rate excluding inflation rate which shows FDI do contribute in economic growth of developing nation in case of Lao PDR and Mongolia. Granger causality test results also indicate that FDI cause GDP growth and unemployment rate strongly, leaving least effect on inflation rate. The study suggested that FDI inflow supported the economic growth and played a crucial role (Anitta, P., \& Mekong Institute, (2013)

In Korea Republic except unemployment rate there is no effect of FDI on economic growth of nation. On one hand it shows significant effect between FDI and GDP and on another it shows lesser effect as compared to other nations. The FDI inflow of Korea Republic stayed inconsistent which can be a reason for these differences.

In case of Sri Lanka, there are evidence that while linking FDI with economy results are inconsistent. A study by Athukorala (2003) stated that the connection between FDI and GDP is not so strong. It found that FDI have no influence on economic growth of host nation. Another study shows that FDI significantly affected the growth rate and noted bidirectional causality between FDI and economic growth (Balamurali and Bogahawatte. 2004). Our study does not show the similar result because of differences in study period. In our study it shows that there is no connection between FDI and economic growth in Sri Lanka.

\section{CONCLUSION}

The study concludes that there is an association between FDI and economic growth in case of Laos and Mongolia. FDI is having its own significance in economic growth of host nation except India and Sri Lanka. There is equivocal result for Bangladesh, China and Korea Republic because there is a significant effect of FDI on economic growth but fragility is found between the studied variable. The study observed that relationship between FDI and Economic growth is unidirectional. The restrictive economic policies of country can be strong argument for variations in result and differences in inflow quantum. The China and India needs to open up it's existing legal obligations on foreign investment because excessive government intervene and tedious paper work can discourage foreign investors.
In this study, based on derived results respective countries need to understand the shallow of foreign investment and trade openness. The lack of strong government foundation in Bangladesh is the greatest challenge for the nation. China's recent adoption of restrictive market policies can cause harm to the FDI inflow in economy. India still needs to create a strong base for routing of foreign investment because excessive government regulations can discourage the foreign investors. Lao PDR, Mongolia and Sri Lanka still need to focus on infrastructure facilities, employability skills and an efficient domestic and foreign investment management.

\section{ACKNOWLEDGEMENT}

The research paper is funded by RUSA (Rashtriya Uchchatar Shiksha Abhiyan) Phase 2.0 Scheme by Ministry of Human Resource Development (MHRD), India. The authors are filled with gratitude to the anonymous referees of journal for their useful suggestions to refine the paper quality.

\section{REFERENCES}

1. Alfaro, Laura. (2003). Foreign Direct Investment and Growth: does the sector matter.

2. AnittaPhommahaxay and Bounlert Vanhnalat, Impact of FDI on economic growth in Lao PDR, ICMR Journal, Volume 3, Number 2, pages 1-18, 2015, http://icmr.crru.ac.th/Journal/Journal\%206/1.pdf

3. Anitta, P., \& Mekong Institute,. (2013). Impact of FDI on economic growth of Lao PDR.

4. Balamurali, N., \& Bogahawatte, C. (2004). Foreign direct investment and economic growth in Sri Lanka. Sri Lankan Journal of Agricultural Economics, 6(1), 37-50.

5. Borensztein, Eduardo and de Gregorio, Jose and Lee, Jong-Wha, How Does Foreign Direct Investment Affect Economic Growth? (March 1995). NBER Working Paper No. w5057. Available at SSRN: https://ssrn.com/abstract=225836

6. Baldwin, Richard \& Braconier, Henrik \& Forslid, Rikard, 1999."Multinationals, Endogenous Growth and Technological Spillovers: Theory and Evidence," CEPR Discussion Papers 2155, C.E.P.R. Discussion Papers https://ideas.repec.org/p/cpr/ceprdp/2155.html

7. Cai, Francis \& Cheng, Huifang \& Xu, LianZan \& Leung, C.K.. (2011). Economic Growth And FDI In China. International Business \& Economics Research Journal (IBER). 3. 10.19030/iber.v3i5.3687.

8. Chandana Chakraborty, Peter Nunnenkamp, Economic Reforms, FDI, and Economic Growth in India: A Sector Level Analysis, World Development, Volume 36, Issue 7, 2008, Pages 1192-1212, ISSN 0305-750X, $\quad$ https://doi.org/10.1016/j.worlddev.2007.06.014. (http://www.sciencedirect.com/science/article/pii/S0305750X080005 $1 \mathrm{X})$

9. Christopher MacDougall, 2015."Foreign Direct Investment into Mongolia," The Northeast Asian Economic Review, ERINA Economic Research Institute for Northeast Asia, vol. 3(2), pages 43-53, October. https://ideas.repec.org/a/eri/review/3243-53.html

10. Ferdausy, Shameema \& Rahman, Md. (2008). Foreign Direct Investment in Bangladesh: A Positive Perspective. 4.

11. Gupta, Kanishka \& Garg, Ishu (2015). Foreign Direct Investment and Economic Growth in India: An Econometric Approach. Apeejay Journal of Management Sciences and Technology 2 (3), June - 2015 (ISSN -2347-5005)

12. J. Gunawardana, Pemasiri \& Sommala, Sisombat. (2009). Trends and Patterns of Foreign Direct Investment in Lao PDR. International Journal of Business and Management. 3. 10.5539/ijbm.v3n1p41.

13. Jha, Raghbendra. (2003). Recent Trends in FDI Flows and Prospects for India. SSRN Electronic Journal. 10.2139/ssrn.431927.

14. Jimmyn Parc, Jin Sup Jung, (2018) "The effects of conventional and unconventional FDI on the host country: A case study of the Korean automobile industry", Journal of Korea Trade, Vol. 22 Issue: 2, pp.105-120,

\section{Policy Implication}


https://doi.org/10.1108/JKT-09-2017-0087

15. Kyophilavong, Phouphet \& Nozaki, Kenji. (2015). Effect of FDI on Lao Economy and its Challenges. Progress Report on the Potentials on the Indochina Economic Zone, Edition: 1, Chapter: CHAPTER 4, Publisher: the Economic and Social Research Institute (ESRI), Editors: the Economic and Social Research Institute (ESRI, pp.59-79).

16. Lai, P. (2002). Foreign direct investment in China: Recent trends and patterns. China and World Economy. 2. 25-32.

17. Mani, Madhavan \& Nithyashree, MU. (2016). Make in India - Foreign Direct Investment and its Impact on Economic Growth. International Journal of Social Science \& Management. Vol. 5. 36-40

18. M M Mustafa, A \& Santhirasegaram, S. (2014). The impact of foreign direct investment on economic growth in Sri Lanka. Journal of Management. 8. 10.4038/jm.v8i1.7551.

19. Mungunzul, Erdenebat \& Chang, Taikoo. (2018). The Effect of Foreign Direct Investment on the Economic Development of Mongolia. Journal of Electronic Commerce in Organizations. 16. 12-21. 10.4018/JECO.2018070102.

20. Nair-Reichert, Usha and Weinhold, Diana, (2001), Causality Tests for Cross-Country Panels: A New Look at FDI and Economic Growth in Developing Countries, Oxford Bulletin of Economics and Statistics, 63, issue 2, p. 153-71.

21. Noorbakhsh, Farhad; Alberto Paloni, and Ali Youssef. 2001. "Human Capital and FDI Inflows to Developing Countries: New Empirical Evidence.” World Development, 29, no. 9:1593- 1610.

22. Ridzuan, Abdul Rahim \& Ismail, Nor Asmat \& Fatah, Abdul \& Idham, Mohamad \& Pardi, Faridah. (2017). The Impact of Foreign Direct Investment and Trade Liberalization on Economic Growth, Income Distribution and Environmental Quality: The Comparative Analysis between France and South Korea. International Journal of Academic Research in Business and Social Science. 7. 163-182. 10.6007/JJARBSS/v7-i6/2953

23. Ravinthirakumaran, Kalaichelvi \& Selvanathan, Eliyathamby \& Selvanathan, Saroja \& Singh, T. (2015). Determinants of Foreign Direct Investment in Sri Lanka. South Asia Economic Journal. 16. 233-256. 10.1177/1391561415598458.

24. Rahaman, A., \& Chakraborty, S. (2015). Effects of Foreign Direct Investment on GDP: Empirical evidence from developing country. Advances in Economics and Business, 3, 587-592. doi: 10.13189/aeb.2015.031207.

25. Sasi Iamsiraroj, Mehmet Ali Ulubaşoğlu, Foreign direct investment and economic growth: A real relationship or wishful thinking?, Economic Modelling, Volume 51, 2015, Pages 200-213, ISSN 0264-9993, https://doi.org/10.1016/j.econmod.2015.08.009. (http://www.sciencedirect.com/science/article/pii/S02649993150021 38) 